\title{
EFFECT OF CONFRONTING BRAND AND EXPERIENCE OF BRAND ON REMEMBERING BRAND (CASE STUDY: CONSUMERS OF SHAMPO IN RASHT)
}

\author{
Mahsa Ghaffari Abkenarei \\ Department of business management, Rasht Branch, Islamic Azad University, Rasht, Iran \\ Seyyed Mohammad Noe Pasand Asil \\ Department of Management, University of Guilan, Rasht, Iran \\ Noepasandasil@guilan.ac.ir
}

\begin{abstract}
Present research aims to investigate The Effect of Brand Exposure and Brand Exprience on Brand Recall through perceived brand image, self-image congruence and trust. This study is descriptive and in aim is functional and in terms data collection is field. Data collecting tool is questionnaire which contains 21 questions to measure the research variables. To measuring the variables from the whole 5-point Likert was used. Reliability using Cronbach's alpha was reviewed and approved. The population of the study is all Shampoo Consumers in Rasht. Using a Cochran formula 390 subjects were evaluated for the study. To test the hypothesis, methods of structural equation modeling was used. The results showed that Brand Exposure has a Psitive and significant effect on perceived brand image and self-image congruence. While has not significant effect on trust. On the other hand, Brand Exprience has a positive and significant effect on all three variables such perceived brand image, self-image congruence and trust. Also all three mediating variables has a significant effect on brand recall.
\end{abstract}

Keywords: Brand Exposure, Brand Exprience, Brand Image, Self-image Congruence, Trust, Brand recall

\section{INTRODUCTION}

The importance of brand reminding is an certain work for specialties and researchers. The thing that needs more attention is that what factors enables consumers to remember brand and fallowing that repurchase it. However about remembering bran there is deep crack between theoretical and practical discussions especially in remembering brand that we concentrated on the this subject exactly and will do necessary consideration for decreasing this crack (Schmitt, 2009). About the way of consumer relationship with a brand many consideration has been done in different forms and methods. However this subject has been proved well that remembering brand has close relationship with confrontation of consumers with brand and their experience (Baumann et al, 2015). Both these two concepts are about the way of consumer's interaction with a brand. However there is obvious difference between these two concepts. Confrontation firstly points confronting advertisement and is considered as one indirect confrontation. In contrast experience of a brand is a mental and internal concept and is related to a consumer of brand or good (Delgado Ballester et al, 2012).

Having previous experience of using a brand leads to better remembering of that information. Some researchers state that knowledge of customer about a product is achieved due to using and buying a product. Whereas some other achieved the point that confronting a brand has deeper effect to experiencing that brand. Concept of confrontation and experience of brand totally are considered as 
familiarity with a brand and by some researches it has been shown that more familiarities with a brand can lead to better reminding of the brand (heckler et al,2012).

Regarding importance of confrontation and experience of brand and remembering brand current research tries to consider relationship between two variables regarding mediating role of perceived image and internal coordination and reliance and is going to answer this question: does Brand Exposure and Brand Exprience affect mediating role of perceived brand image, self-image congruence and trust among consumers in Rasht city?

\section{LITERATURE REVIEW}

Remembering brand means ability of consumer I recycling brand when by class of product faces need met by class of product or other symptoms. In other word remembering brand needs consumer read product from its memory correctly. It is much important that only depth of remembering (percent of people who know brand) should not be measured but its width (symptoms that lead to reminding brand) should be measured. A good story for assessing brand is thinking about this point that who, when and how buy the brand and use it. In summary remembering brand is rapid and immediate awareness of a specific brand (valls et al, 2011). Therefore simultaneous with severe competition a brand should have more capability toward other competitors. Consumer theory showed that process of reminding like other behavioral process of consumer is affected by affection and emotions(Baemen et al, 2015).

On the other hand nature of experience of brand has beenconsidered since beginning of 1980 but this concept was identified by Schmit for the first time in 1997. Brand experience is resulted from a set of interaction between customer with a brand a company or part of an organization(schmit,2009). Brand experience includes emotional, behavioral and cognitive reaction stimulated by generators related to brand like design, identity, packing, communication and environment in which brand is supplied. Many authorities of marketing believe that identification and perception of the way of brand experience by consumers is vital for marketing strategies of product because brand experience is used in predicting behavior of consumer (Brakus et al, 2009). Brand experience can happen directly or indirectly. Direct experience of consumer is created from physical contact of a product and indirect experience is resulted from advertisement or marketing communication. Brand experience can be short-term or long-term ad positive or negative (Albert \& Merunka, 2013).

Brakus et al knew brand experience as a 4-dimensional construction that are:1-emotional dimension: concentration of emotional dimension of brand experience on sense of sight, smell, taste and touch of consumer. Emotional sense shows attractiveness of a brand for emotion of consumer and shows it effect on his emotion.2-affective dimension: affective dimension points affection ad internal emotion of consumer toward a brand.3- cognitive dimension(intellectual) of brnd experience includes creative thinking of a consumer.4- behavioral dimension: behavioral dimension points goal of physical experience of life of consumer. This dimension shows involving physical activity (Motaharinezhad et al, 2014).

When discriminating product or services is based on qualitative tangible features or even good and services are similar, purchasers show different reaction toward mental image of company or brand of productive goods. Any brand has a personality that the personassimilate himself with it (Hng \& cho, 2011). Plsmer (1985) counts mental image as perception of consumer about brand personality but personality of brand is he result of company communication withcustomers. Katler (2001) has defined image as a set of believes, idea and image that a person has about a thing. This association can result from direct experience and or is resulted from obtained information presented from market or due to effect of available association that organization had on consumer. Therefore brand image is mental image or perception of a brand or a product or signed serviceand includes symbolic meaning that consumers associate with especialfeatures of a product or service (Ebrahimi and mansori, 2013). 
Reliance of brand is the most important feature of a brand. Investment on brand is in the form of investing advertisement or supporting sport team, through encouraging companies to honesty in their claims about the product, a basis for brand reliance. Also compatibility og strategies combined with marketing with stated goals and fixing strategies along time and clarity of performance adds brand reliance. Finally brand reliance decrease perceived risk by customer while buying good and cost of acquiring information by him for buying it and also affects perceived quality by him. these three factors cause increase of expected favorability of purchasing good and he is motivate to buy the brand (Dehghani soltani et al, 2013).

Different research has shown that goods and brands are not only used due to their functional goals but it is one reason of using brand is meaning and symbolic values that provide for consumers. Also research have shown that consumers feel images that is reflected by a good for brand can represent real person and his internal sense or development of his personality and this co-thinking concept with brand can increase value of a brand. Adaption of bran with personality of consumer depends on perception of consumer about brand image or its associations (Baemen et al, 2015).

In current researchvariables of confronting brand and brand experience have been considered as independent variables. Also three variables $\mathrm{f}$ brand perceived image, internal adaption and reliance to brand are considered as moderating variable and finally variable of brand remembering that is the main goal of research is considered. Therefore regarding main goal of research and considering problem, conceptualmodel of current research s taken from studies of Bawman et al (2015) that is presented as figure 1:

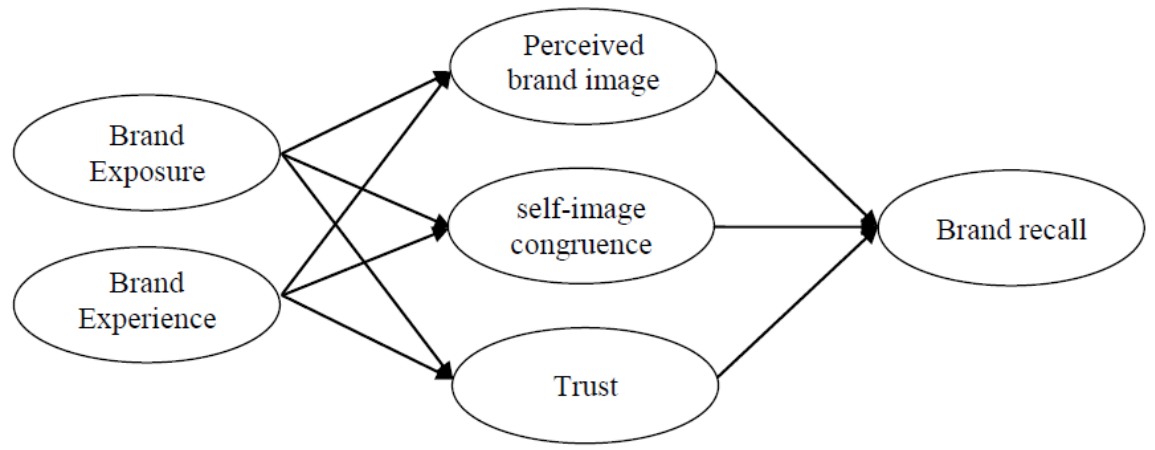

Figure 1: Conceptual model of research(Baumann et al, 2015)

Based on Research model, Hypothessis of research are as follow:

H1: Brand Exposure has a significant effect on Perceived brand image.

$\mathrm{H} 2$ : Brand Exposure has a significant effect on self-image congruence.

H3: Brand Exposure has a significant effect on Trust.

H4: Brand Experience has a significant effect on Perceived brand image.

H5: Brand Experience has a significant effect on self-image congruence.

H6: Brand Experience has a significant effect on Trust.

H7: Perceived brand image has a significant effect on brand recall.

H8: self-image congruence has a significant effect on brand recall.

H9: Trust has a significant effect on brand recall.

\section{METHODOLOGY}

Statisticalsociety of current research isconsumers of Shampo in Rasht city. Sampling method in current research was chosen through available improbable method. By using Cochran sampling formula minimum sample was estimated 355 people. For achieving considering samples 400 questionnaires were distributed among consumers that 390 ones were correct and collected. For collecting considering data a 
questionnaire including 21 items have been used. For analyzing hypothesis of research and testing model structural equation modeling was used.

\section{RESEARCH FININGS \\ Descriptive research}

Based on analyzing collected data, $66.9 \%(261$ people) of statistical samples were female and 33.1\%(129 people) were male. The highest frequency of education was form B.A(170 people) and the least frequency was related to M.A and higher education(23 people). The highest frequency of age is for 30-40 (137 people) and the least frequency related to over 50 years old(64people).Also in table 1 research variables have bee considered based on index like mean, standard deviation, maximum and minimum.

Table 1: Descriptive analyzing of variable

\begin{tabular}{|c|c|c|c|c|c|c|}
\hline & $\mathrm{N}$ & Min & Max & Mean & S.D. & Cronbach Alpha \\
\hline Brand Exposure & 390 & 1 & 5 & 3.1359 & 0.87831 & 0.711 \\
\hline Brand Experience & 390 & 1 & 5 & 3.3844 & 0.84762 & 0.835 \\
\hline Perceived brand image & 390 & 1 & 5 & 2.7917 & 0.86935 & 0.790 \\
\hline self-image congruence & 390 & 1 & 5 & 2.8817 & 0.98950 & 0.724 \\
\hline Trust & 390 & 1 & 5 & 3.1906 & 0.82773 & 0.884 \\
\hline Brand Recall & 390 & 1.33 & 5 & 3.5063 & 0.80878 & 0.820 \\
\hline
\end{tabular}

Regarding result mentioned in table 1 it is regarded brand remembering has achieved the highest mean and devoted the least mean to itself. Also all variables are located at relatively moderate level.

\section{Testing hypothesis}

In fig 2 and 3 structural equation modeling of main hypothesis has been shown in meaningful coefficient mode and structural coefficient. As in meaningful coefficient mode t statistic is out of range +1.96 and 1.96 hypothesis is approved. Also structural coefficient shows relationship or effect of independent variable on dependent variable. Based on these charts we can calculate indirect effect of confronting brand and brand experience on remembering brand through moderating role of perceived image, internal adaption and reliance to a brand. Fit index showed in table 2 denotes to what extent designing model was proper and adapt with data that researcher collected.

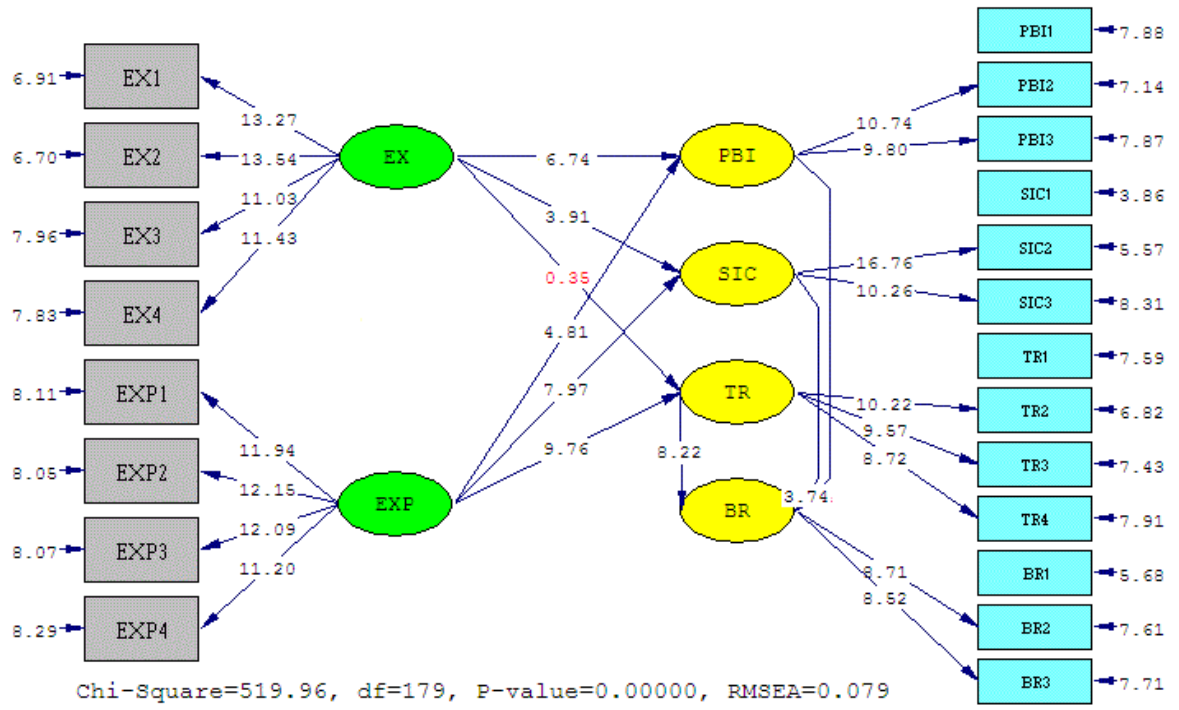

Figure 2: Research model in Meaningful coefficient mode 


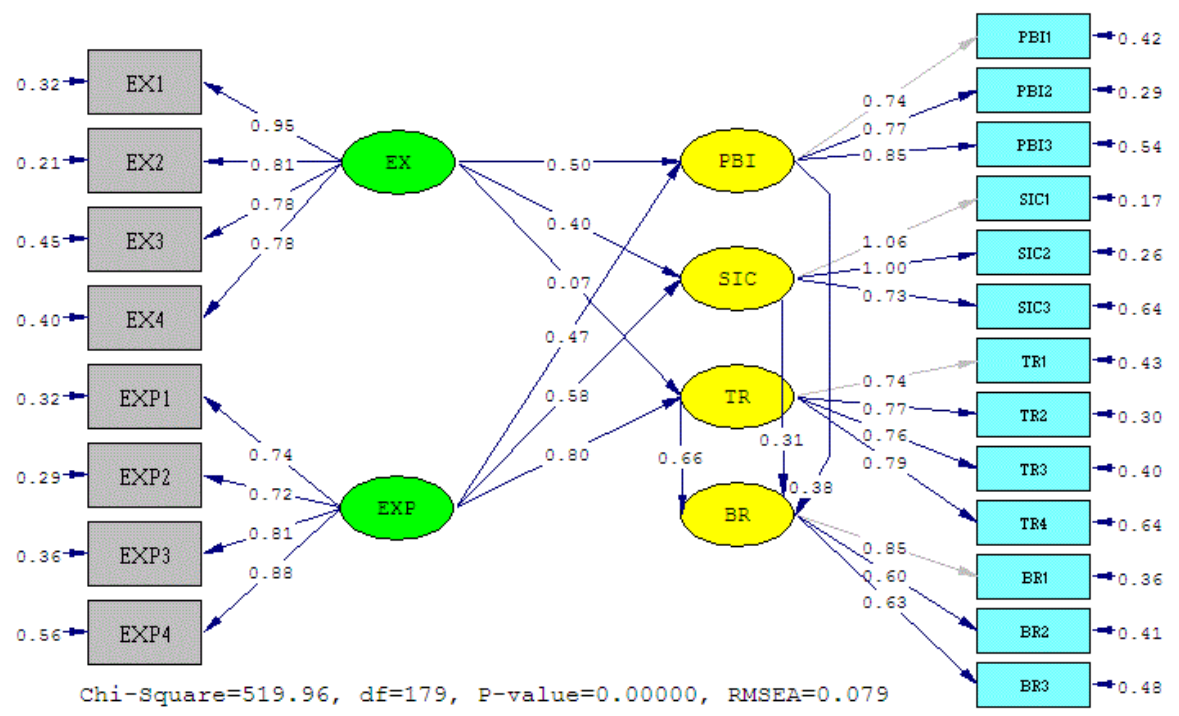

Figure 3: Research model in Standard Coefficient mode

\section{Fit index of model}

Fit index of mode of research that is in table 2 shows that model has proper fitting with data collected from statistical samples of research. That is this model shows relations correctly.

Table 2: Fit indices of model

\begin{tabular}{|c|c|c|c|c|c|c|c|}
\hline Indices & AGFI & GFI & CFI & NNFI & NFI & $\chi^{2} / \mathrm{df}$ & RMSEA \\
\hline Obtained value & 0.87 & 0.90 & 0.92 & 0.91 & 0.90 & 2.905 & 0.079 \\
\hline Fit value & $0.8<$ & $0.9<$ & $0.9<$ & $0.9<$ & $0.9<$ & $3>$ & $0.08>$ \\
\hline
\end{tabular}

\section{Analyzing Path of hypothesis}

In table 3 all direct ways are based on research hypothesis and also meaningfulness numbers and t-value was shown and so we can do necessary consideration for approving or rejecting hypothesis.

Table 3: Direct path of model

\begin{tabular}{|c|c|c|c|c|c|c|}
\hline $\mathrm{H}$ & \multicolumn{3}{|c|}{ Path } & $\mathrm{B}$ & $\mathrm{t}$ & Result \\
\hline $\mathrm{H} 1$ & Brand Exposure & to & Perceived Brand Image & 0.50 & 6.74 & Accept \\
\hline $\mathrm{H} 2$ & Brand Exposure & to & Self-image Congruence & 0.40 & 3.91 & Accept \\
\hline $\mathrm{H} 3$ & Brand Exposure & to & Trust & 0.07 & 0.35 & Reject \\
\hline $\mathrm{H} 4$ & Brand Experience & to & Perceived Brand Image & 0.47 & 4.81 & Accept \\
\hline H5 & Brand Experience & to & Self-image Congruence & 0.58 & 7.97 & Accept \\
\hline H6 & Brand Experience & to & Trust & 0.80 & 9.76 & Accept \\
\hline $\mathrm{H} 7$ & Perceived Brand Image & to & Brand Recall & 0.38 & 3.74 & Accept \\
\hline $\mathrm{H} 8$ & Self-image Congruence & to & Brand Recall & 0.31 & 3.12 & Accept \\
\hline H9 & Trust & & Brand Recall & 0.66 & 8.22 & Accept \\
\hline
\end{tabular}

\section{Indirect effect}

In Table 4 indirect ways has been shown for considering moderating role of perceived image, internal adaption and reliance to a brand.

Table 4: Indirect path of model 
The Turkish Online Journal of Design, Art and Communication - TOJDAC July 2016 Special Edition

\begin{tabular}{|lllll|c|c|}
\hline Brand Exposure & to & Perceived Brand Image & to & Brand Recall & 0.190 & $(6.74) \times(3.74)$ \\
\hline Brand Exposure & to & Self-image Congruence & to & Brand Recall & 0.124 & $(3.91) \times(3.12)$ \\
\hline Brand Exposure & to & Trust & to & Brand Recall & & $(0.35) \times(8.22)$ \\
\hline Brand Experience & to & Perceived Brand Image & to & Brand Recall & 0.179 & $(4.81) \times(3.74)$ \\
\hline Brand Experience & to & Self-image Congruence & to & Brand Recall & 0.180 & $(7.97) \times(3.12)$ \\
\hline Brand Experience & to & Trust & to & Brand Recall & 0.528 & $(9.76) \times(8.22)$ \\
\hline
\end{tabular}

As it is obvious regarding meaningfulness of $\mathrm{T}$ statistic we can conclude that perceive image of brand internal adaption of brand and reliance to brand plays moderating role in relation 5. Only in relationship between confronting brand and remembering brand, reliance to brand doesn't have moderating role.

\section{CONCLUSION AND DISCUSSION}

Confronting brand is doe through different ways like advertisement of companies, through shops presenting product and through friends and acquaintance and internet. Therefore it is suggested productive companies or representative of foreign brands of shampoo in Iran make confrontation of people with their shampoo more by using advertising strategies such as strong and effective environmental advertisement and word of mouth advertisement about the product and using artificial atmosphere for affecting potential consumers of shampoo brand. Because through increasing people's confrontation withbrand in different atmosphere in which they present, weather real or artificial atmosphere they can create better image of the product in mind of customers and consumers. On the other hand confronting brand affects internal adaption of brand. Therefore this point is suggested to marketers and authorities of producing companies that through increasing their advertisement in dual atmosphere for people put the need to their products in unconsciousconscience of potential customersand consumer feel positive internal adaption with considering shampoo. Also brand experience has positive effect on brand perceived image. In fact the most real perceived image by customer is while experiencing using shampoo. Therefore it is suggested to increase percent of buying shampoo through different ways like adding cage related to shampoo in shops and after creating positive and good experience for consumer have this positive perceived image in mind of customer for a long time and benefit repurchasing. Result of research showed that brand experience has positive effect on internal adaption of brand. Therefore it is suggested marketers and authorities of producing shampoo brand make compatibility of especial brand with internal interest of consumers more through concentration on creating good experience for consumer. Also positive experience of using product can attract reliance of consumer. Honest advertisement can besides creating positive brand experience make their reliance more for repurchasing. Result of research showed that perceived image of shampoo brand, internal adaption of brand wit consumers and reliance of consumers to a brand has meaningful and positive effect on brand. Therefore it is suggested by exact attention to these factors and planning marketing strategies and proper sale, consider mental image of consumers and internal adaption of brand with internal interest of consumers and reliance of consumer to the brand in order to increase power of remembering shampoo brand.

\section{REFERENCES}

1. Albert, N., Merunka, D. (2013), The role of brand love in consumer-brand relationships, Journal of Cunsumer Marketing, 3 (3), pp. 258-266.

2. Baumann, Ch., Hamin, H., Chong, A. (2015), The role of brand exposure and experience on brand recall-Product durables vis-à-vis FMCG, Journal of Retailing and Consumer Services, 23, 21-31.

3. Brakus, J. J., Schmitt, B. H. and Zarantonello, L. (2009), Brand experience: What is it? How is it measured? Does it affect loyalty?, Journal of Marketing, 73 (3), pp. 52-68.

4. Dehghani Soltani, M., Mohammadi, E., Pourashraf, Y., Sayehmiri, K., Ghahri shirinabadi, E. (2013), Approach of structural equation modeling in explanation of effect of experience, reliance and loyalty to a brand on brand especial value, marketing management journal, 21, 102-107. 
5. Delgado-Ballester, E., Navarro, A., Sicilia, M., (2012), Revitalising brands through commu-nication messages: the role of brand familiarity. Eur. J. Mark. 46 (1/2), 31-51.

6. Ebrahimi, A., Mansouri, S. H. (2013), Considering effect of mental image of brand and quality of services on relationship marketing and behavioral tencencyies of customers, business management viewpoint, No 14, 153-170.

7. Heckler, S. E., Keller, K. L., Houston, M. J., Avery, J. (2012), Building brand knowledge structures: Elaboration and interference effects on the processing of sequen-tially advertised brand benefit claims. J. Mark. Commun. 1-21, (ahead-of-print).

8. Hong, I. B., Cho, H. (2011), The impact of consumer trust on attitudinal loyalty and purchase intentions in B2C e-marketplaces: Intermediary trust vs. seller trust. International Journal of Information Management 31: 469- 479.

9. Motaharinezhad, F., Samadi, S., Tolabi, Z., Pourashraf, Y. (2014), Considering relationship between brand and consumer (case study of electrical apparatus), marketing management journal, No 3, p 130 .

10. Schmitt, B. H. (2009), The concept of brand experience, Journal of Brand Management, 16 (7), pp. 417-419.

11. Valls, J. F., Andrade, M. J., Arribas, R. (2011), Consumer attitudes towards brands in times of great price sensitivity: four case studies. Innov. Mark. 7 (2), 60-70. 